\title{
BEVERĪNAS MEKLĒJUMU ATRISINĀJUMS
}

\section{GINTS SKUTĀNS}

Mg. hist.

E-pasts: skutans@inbox.Iv

\begin{abstract}
ANOTĀCIJA
Vairāk nekā simt piecdesmit gadu ilgst "Livonijas Indriḳa hronikā" pieminētās Beverīnas pils meklējumi, taču līdz pat šim brīdim nav bijis iespējams nonākt pie vienota slēdziena. Pašlaik arheologiisko izrakumu un rakstu avotu izpētes rezultātā vairākumu pils novietojumu vietu Valmieras apkārtnē iespējams noraidīt, jo šai apvidū nav konstatējama 11.-13. gadsimta apdzīvotība. Izanalizējot Kauguru Pekas kalna uzbūvi un izrakumu materiālu, nocietinājuma pastāvēšanas laiku izdodas attiecināt tikai uz 14.-16. gadsimtu. Līdz ar to Beverīnas lokalizāciju iespējams veikt vienīgi atlikušajā Raunas Tanīsa kalnā, kurš atbilst visiem hronikā fiksētajiem kritērijiem. Arheologiiskie pētījumi pilskalnā atrod nozīmīgu vēlā dzelzs laikmeta nocietinājumu, bet piegulošā novada apdzīvotībai raksturīga blīva arheolog̉isko pieminekḷu koncentrācija. Tā kā nav prognozējamas jaunas vēsturnieku publikācijas Beverīnas meklējumu turpināšanai, šo pagātnes noslēpumu varam uzskatīt par atrisinātu.
\end{abstract}

Atslēgas vārdi: Beverīna, pilskalns, pils, vēsturiskā geogrāfija, Livonija, "Indriḳa hronika", viduslaiki.

Beverīnas pils atrašanās vietas mīkla Latvijas historiogrāfijā ir palicis neatbildēts jautājums, bez kura nav iespējams izprast Vidusvidzemes vēlā dzelzs laikmeta ǵeogrāfiju. Pils piecpadsmit reizes pieminēta "Indriķa hronikā" (turpmāk tekstā hronika) kā Tālavas nocietinājums Beverin, piederīgs kompaktai letu grupai (turpmāk tekstā latvieši) Gaujas vidustecē. Tie aizṇēma kādu biezi apdzīvotu, zemkopībai piemērotu apvidu un apzīmēti hronikā kā Letti de Beverin, Bevernenses. Beverīnas vārds ir ieņēmis zīmīgu vietu Latvijas kultūrvēsturē, un īpašu oreolu tam pieškiir hronikā aprakstītā priestera muzicēšana 1208. gada aplenkuma laikā. Jau vairāk nekā simt gadu pils meklējumi veido stūrakmeni Valmieras, Trikātas un Vijciema 
novadpētnieku aktivitātēs. Starpkaru gados lokalizācijas aptvēra septiñas vietas - Valmieru (pilsdrupas, Lucas kalns), Kaugurus (Pekas kalns), Rubeni (Vaidavas pilskalns), Trikātu, Vijciemu, Burtniekus un Raunu (Tanīsa kalns). Taču pēdējos trīsdesmit gados pils novietojumu skaits ir dubultojies, turpinājusies polemika presē, organizēta konference un priekšlasījumi, notikušas ekskursijas un talkas. Sastopami arī iracionāla un ezoteriska rakstura novietojumi, diskutēts par Beverīnas dziedoṇa un viña instrumenta noslēpumu. Pašlaik Beverīnas meklētāju loks ir stipri sašaurinājies, bet arheolog̣isko izrakumu un rakstu avotu izpētes rezultātā Gaujas labā krasta novietojumi zaudējuši savu aktualitāti. Adekvāto meklējumu lokā palicis trīsstūris starp Raunu, Valmieru un Trikātu. Raksts tapis ilgstošas pētniecības gaitā un ir noformēts akadēmiski korekti, lai starp atlikušajiem pretendentiem pārliecinoši pamatotu galīgo risinājumu.

Pētijums ilgst trīsdesmit gadu, balstās uz hronikas (IH 1993) un arheolog̣ijas ziṇu salīdzināšanu, veicot arī objektu apsekošanu dabā. Pašlaik Ziemeḷvidzemē un piegulošajā Igaunijā ir apsekoti visi viduslaiku nocietinājumi, izpētìtas rakstos pieminēto kauju un ceḷu vietas. Jānorāda, ka hronikā par Beverīnu ir daudzpusīgs ziņu klāsts, atšķiirībā no Sateklas vai Metimnes. Mēs varam noteikt attālumus līdz Cēsīm un Sakalai, tāpat zināms, ka pils atradusies nozīmīgu ceḷu tuvumā, jo no šejienes sākti vismaz trīs karagājieni uz Igauniju un pati pils divas reizes aplenkta. Skaidrota robežligumos starp Zobenbrāḷu ordeni (turpmāk tekstā ordenis) un Rīgas bīskapu pieminēto Ziemel̦vidzemes vietu ǵeogrāfija (SLVA 79; Abuls 1924, 45), kura l̦auj izprast ar Beverīnu saistīto teritoriju sadalǐšanas principus 1209.-1224. gadā. Izmantoti arhibīskapa Fromolda izdotie dokumenti (LGU I, 90-91), ieraksti Rīgas parādu grāmatās (RS, 1-119), caurskatīti Livonijas un Hanzas pilsētu tirdzniecības dokumenti. Apzinātas 16. gadsimta cel̦otāju Zamuēla Kīhela (Spekke 1995, 112-115) un Heinriha Štādena atmiņas (Dunsdorfs, Spekke 1964, 297), kuras atklāj muižu pastāvēšanas faktu divos Beverīnas meklējumu apvidos. Apzinātas arī arheolog̣ijas materiālu ziņas par senākajiem un mūsdienu izrakumiem pils meklējumu vietās.

Beverīnas meklējumu pirmskara historiogrāfija sīki apskatīta līdzšinējās publikācijās, kuras brīvi pieejamas internetā (Abuls 1924; Žīgurs 2003 u. c.), tāpēc aplūkošu tikai jaunākās pēdējo trīsdesmit gadu norises. Arheologs Pēteris Stepiņš vēl padomju laikā atjauno Beverīnas meklējumus (1983, 1992, 1993), novietojot to Vaidavas pilskalnā. Arī Ēvalds Mugurēvičs vairākās publikācijās (1965., 1993., 1999. gadā) pamato savu Trikātas variantu (IH 1993, 376), līdz 1993. gadā izveidojas polemika ar P. Stepiṇu. Pirmais jautājuma kopsavilkumu 1991. gadā publicē Juris Urtāns, aprakstot Ziemelvidzemes pilskalnus (Urtāns 1991, 9-12, 38). Taču no paša izvirzìtās Viḷumu versijas (1988) pētnieks tūlin atsakās, jo skaidras pilskalna pazīmes kalnā neizdodas konstatēt. Publikācijas autors Beverīnas pili līdz 


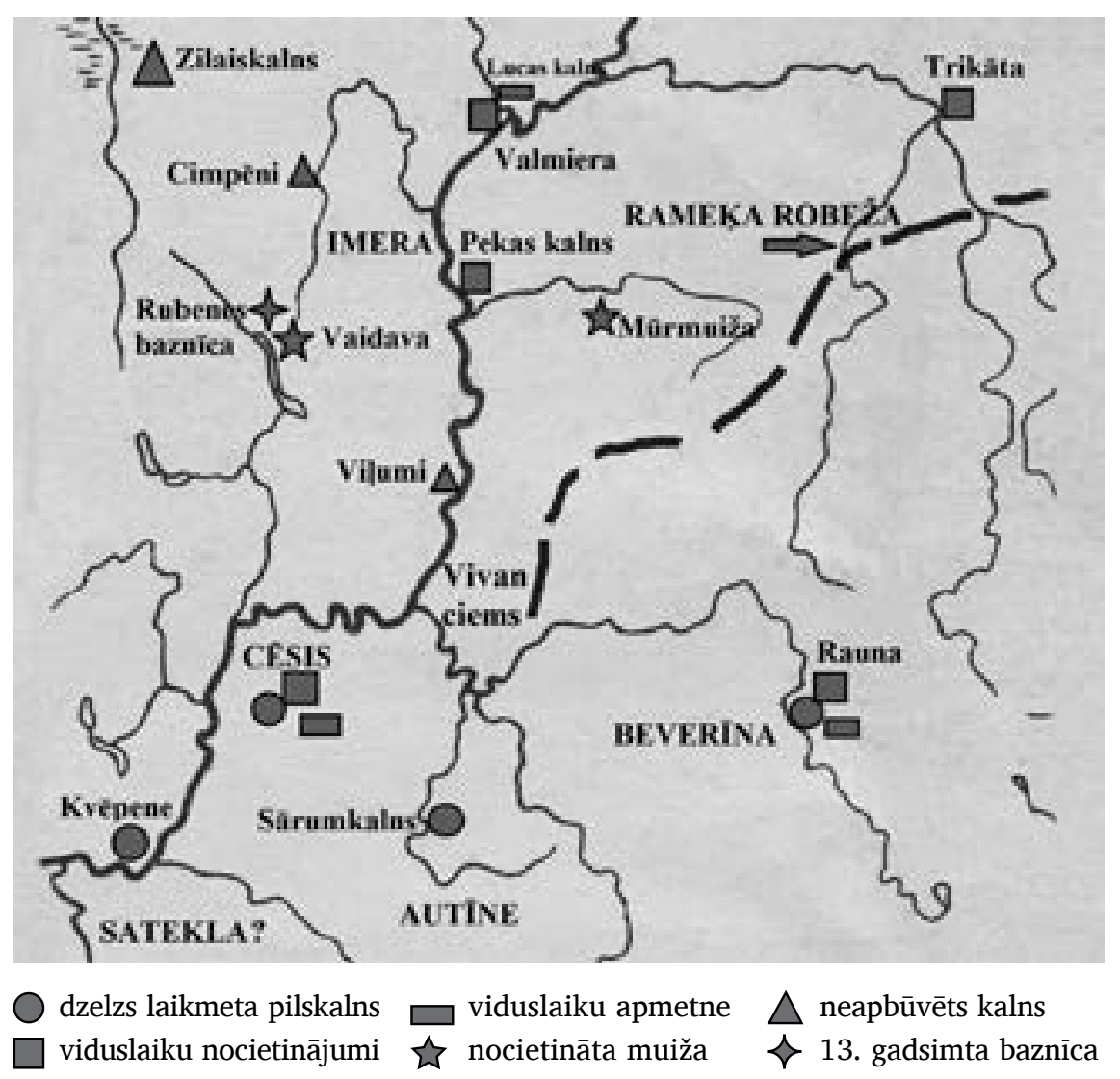

1. attēls. Beverīnas galvenie novietojumi un publikācijā pieminētās 13.-16. gadsimta vietas Gaujas vidustecē. Izstrādājis G. Skutāns 2021. gada maijā

Figure 1. The main locations of Beverina and the $13^{\text {th }}$ to $16^{\text {th }}$ century areas in the middle reaches of the Gauja noted in the publication. Developed by G. Skutāns in May 2021

šim saistījis ar Raunas Tanīsa kalnu, bet Sateklu ir mēginājis novietot dažādās vietās (Kvēpene, Līgatne u. c.) rietumos no Cēsīm (Skutāns 1992, 65; 2010). Lai arī meklējumi ilguši vairāk nekā trīsdesmit gadu periodu, autors vēl arvien nevar dot izsmel̦ošu atbildi par Sateklas pils novietojumu. Muntis Auns Beverīnu novietoja Cimpēnu pilskalnā (1996), taču šo versiju pats vēlāk atzina par pārsteidzīgu. Novietojumus un to argumentāciju ir uzskaitījis Edgars Žīgurs, kura veidotais pētniecības apskats ir plašākais par šo tēmu. Savā studiju darbā viņš piedāvā lokalizācijām novērtējuma tabulu - "Beverīnas hipotēžu verifikāciju”, kurā izvirzās Pekas kalns un Rauna (Žīgurs 2003, 1. pielikums). 2001. gadā notika Beverīnas meklējumu kulminācija, Valmieras muzeja organizētā konference "Es meklēju Beverīnu". Tajā piedalījās Guntis Zemītis, Tālis Pumpuriņš, Gints Skutāns, Andrejs 
Lucāns, Eduards Lauris, Valentīns Klešniks, Ojārs Ozolinš u. c., taču konferences materiāli ir palikuši nepublicēti. Turpināja pastāvēt arī Artūra Gobas (1990) un Ojāra Ozolin,a atbalstītā Vijciema versija, kura pašlaik zaudējusi jebkādu nozīmi. Ap 1990. gadu O. Ozoliņš tomēr maina uzskatus par labu Valmieras apvidum, klusībā cerēdams Gaujas kreisajā krastā atklāt jaunu, Beverīnai piemērotu pilsvietu. Valmieras versiju noliedz ilgstošā pilsdrupu arheoloǵiskā izpēte - senākā 1937.-1939. gada, tā arī padomju laika (Berga 2018, 21; 34) un it sevišḳi 2018. gada izrakumi (Brūzis 2019, 47). Izpētot lielu daļu no Valmieras pils teritorijas, netika atrasta pirmsvācu apdzīvotība, līdz ar ko iespējams pilnībā noraidīt Hermaṇa Enzeliṇa (1935) un A. Lucāna (Lucāns 1996, 4) paustos uzskatus. Meklējumu saistībā E. Lauris Trikātas pilsdrupās saskata senu pilskalnu, par ko atkārtoti rakstījis vietējos izdevumos (Lauris 2019, 6 u. c.).

Beverīnas lokalizācijas varam sadalīt divās grupās, no kurām nopietnākajai saskaṇā ar hronikas ziṇām (IH XII: 6) atbilst samērīgs attālums līdz Cēsīm (ne vairāk kā 30-35 kilometri) un pilskalna ierīkošanai atbilstoša vieta. Meklējumu priekšgalā nonāk deviṇi kandidāti (sk. 1. attēlu) - Kauguru Pekas kalns, Rauna, Trikāta, Rubene, Valmieras pilsdrupas un Lucas kalns, Zilaiskalns, Viḷumi (Vaidavas pagastā) un Cimpēni. Pašlaik apzinātas līdz pat divdesmit Beverīnas novietojuma versijas, taču pusei no tām argumentācija nav nopietni uztverama. Aston,os no ticamākajiem Beverīnas novietojumiem ir notikuši dažādas kvalitātes arheologiskie izrakumi. Ja vien tiktu apkopoti agrāko izrakumu pārskati un veikti nopietni datējumi, šis vēstures noslēpums jau sen būtu atrisinājies.

Pētījumi Valmierā, Vaidavā, Cimpēnos un Trikātā nav devuši uz 12.13. gadsimta miju attiecināmus atradumus. Apdzīvotības pazīmes netika atrastas Cimpēnos (Ballod 1911, 26) un Zilajā kalnā (1874., 1973., 2020. gada izrakumi), bet t. s. Viḷumu pilskalna smilšu atsegumos nav kultūrslān,a pazīmju. Pekas kalns vēstures literatūrā tiek atzīts par 12.13. gadsimta nocietinājumu, taču mūsdienu pētniecība (Ose, Caune 2004, 244) šeit konstatē izteiktu 15.-16. gadsimta apbūvi, tiesa gan, neapstrīdot Franča Baloža uzrādītā 12.-13. gadsimta slāṇa pastāvēšanu. No jauna ir jāpārbauda viņa atzinumu objektivitāte, jo pētnieks tolaik bija ieinteresēts pamatot sava tēva Voldemāra Baloža uzskatus (Ballod 1910; 1911; Balodis 1928). F. Balodis 1909. gadā, būdams arheologijas students, pievēršas pilnīgi jaunai tēmai - pilskalnu pētniecībai, kura šai laikā visu Baltijas guberņu mērogā spēra pirmos soḷus.

Beverīnas meklējumos līdz šim maz akcentēta pilskalnu tipologijas metode, kuru Ernests Brastiņš veido, balstoties uz pilskalnu uzmērīšanas pieredzi. Tā l̦auj pēc ārējo pazīmju kopsakarības dzelzs laikmeta koka pilis nošḳirt no 13.-15. gadsimta vācu nocietinājumiem, 16.-17. gadsimta muižu vietām, karaspēka nometnēm un skanstīm. Pēdējos sešdesmit gados 
arheolog̣iski pētīti arī 13. gadsimtā vācu ierīkotie viduslaiku nocietinājumi Krusta kalns Siguldā (Jemeljjanovs 2010, 88), Liepupes pilskalns (Kraukle 2016, 188), Žagares Zvelgaiču kalns (Vasiḷausks 2014, 99) u. c. Tie parasti tiek pieskaitīti dzelzs laikmeta pilskalniem, jo tajos akmens mūrējumi nav bijuši vai arī vairs nav atpazīstami zemes virskārtā. No vietējo tautu nocietinājumiem tie atšķiras ar regulāras formas plakumu, zemu vaḷnu uzbērumiem un aizsarggrāvjiem nocietinājuma perimetrā. Vadoties pēc šādām pazīmēm, Beverīnas meklējumu rajonā kā vācu laika koka nocietinājumus varam identificēt Dzērbenes Augsto kalnu, Cērtenes un Naukšēnu pilskalnu (Brastiņš 1930, 96, 182, 208). Atšḳirīga un kompakta vēlā dzelzs laikmeta nocietinājumu grupa izvietojusies krietni dienvidos no Valmieras - Cēsu un Straupes apkārtnē. Šiem pilskalniem vērojams pavisam citu pazīmju kopums - visvieglāk pieejamā pusē ierīkots ap desmit metru augsts priekšvalnis, plakums ir iegarens un neregulārs, pārsvarā gadījumu kalnā uziet varēja pa kreiso pusi. Tādas vērojamas Straupes Kranču kalnā, Kvēpenē, Sārumkalnā, Tanīskalnā (Brastiņš 1930, 79, 87, 90-93) un Dzērbenes Ketu pilskalnā (Urtāns 1995, 23). Gaujas labajā krastā un līdz pat Igaunijai 9.12. gadsimta nocietinājumus, apmetnes un apbedījumus arheologijijas kartes neuzrāda (LA 178-179), tas pats vērojams vēl 15 kilometru aiz robežas (EE, 20. attēls). Ir jāpārvērtē šìs teritorijas apdzīvotības blīvums, celtniecības un apbedījumu tradīcijas.

No Gaujas labā krasta versijām apskatīšu tikai Beverīnas lokalizāciju Rubenē, jo zināms stāsts par Livonijas kara laika zemes nocietinājuma pastāvēšanu tieši šajā vietā. Vācu ceḷotājs Zamuēls Kīhels, braukdams no Rīgas uz Tērbatu trīs gadus pēc Livonijas kara beigām, šeit meklē naktsmājas un atstāj sīku aprakstu šai Beverīnai (Spekke 1995, 114). Vaidavas pilskalns atrodas pavisam netālu no Rubenes baznīcas, Tērbatas lielcela tiešā tuvumā. Izrādās, ka tajā nocietinātu muižu ierīkojis Melhiors Hēfelns (Melchior Höfeln), kurš pēc 1562. gada Vidzemes pievienošanas Polijai ir kḷuvis par karaḷa vasali. Jaunā muiža varēja tikt uzcelta pret krievu iebrukumiem Livonijas kara ceturtajā posmā (1578-1583), kad Cēsis jau bija atgūtas un krievi atspiesti uz Tērbatu. Kīhels 23. jūlijā izbrauc no Rīgas un nakšn,o pie Baltezera, 24. jūlija vakarā apmetas uz lauka Inciema tuvumā, bet nākamajā rītā dodas Valmieras virzienā un nonāk ceḷu krustojumā pie Lielstraupes skolas. Tālāk seko Beverīnas tēmai tik vērtīgais naktsmìtnes apraksts. "[..] Tā nu vakarā mēs nonācām pie kāda muižnieka mājas, kas visapkārt apn,emta ar zemes val,niem; lai tajā varētu patverties pret uzbrukumu, ticis ierīkots pacel̦amais tilts. [..] Šo muižu sauc par Jauno muižu, un tās muižnieku par Melhioru fon Hēfelnu, kurš ir karavīrs un atrodas Polijas k,ēniņa dienestā. Lai gan šî nocietinātā vieta maz nostiprināta (ap to bija tikai zems velēnu valnis), tomēr pagājušā kara laikā maskavieši to nekad neesot varējuši ien,emt; daži apkārtējie 
ciemati, kas atrodas tuvumā, tur nobēdzināja savu mantu, un arī ḷaudis tur patvērās, tā kā [šis cietoksnis] bijis pienācīgi apgādāts ar kareivjiem, lielgabaliem un pulveri." (Spekke 1995, 114-115)

Šì Jaunā muiža pieminēta 1601. gada arklu revīzijā Mujānu pilsnovadā (Melchior fon Höwelen un Newe hoff; Švābe 1933, 549), kur Hēfelns pārvalda īpašumu ar vairāk nekā simt saimniecībām (Ķiegeeḷu, Vaidavas, Podzēnu muiža). Tā kā lēņa novads kara gaitā ir postīts un nedrošs pret sirojumiem, viņš spiests ierīkot jaunu nocietinātu mītni priežu silā, stāvā ezera krastā. Muižas pastāvēšanu apstiprina Jāņa Apala 1986. gadā arheoloğiskie izrakumi, kuri tika veikti trijās atsevišḳās plakuma vietās. Atradumi visur bija vienveidīgi naglas, ripas keramika, kiieǵel̦u lauskas (Apals 1988, 18). Apskatot dabā nocietinājuma uzbūvi, atklājas šaujamieročiem pozīcijām paredzēti, specifiski uzbērumi un trīsstūrveida bastions. Livonijas kara beigu posma zemes nocietinājumi Latvijā pilskalnu vidū vēl nav izdalīti atsevišḳā kategorijā, taču Ziemeḷvidzemē varu uzrādīt vēl vismaz trīs citu analogu esamību.

Trikātas un Kauguru novietojumam priekšroku deva 2009. gada teritoriālā reforma ar Beverīnas novadu, līdz ar ko tālāko meklējumu gaita tika apgrūtināta. Nav viegli no vēstures pozīcijām apstrīdēt administratīvi deklarētu faktu un pārliecināt vietējo sabiedrību par kārtējo pārpratumu, kurš turklāt nākamajā reformā atkal ticis svītrots. Vēl nesen Trikātu atbalstīja arī Latvijas arheolog̣ijas autoritātes - Ēvalds Mugurēvičs un Jānis Graudonis, radot nepamatotus pārpratumus. Jānorāda, ka padomju laikā E. Mugurēvičs necentās akcentēt tādu nevēlamu personu kā F. Baloža un E. Brastiņa pārstāvētās Beverīnas versijas. Diemžēl Trikātu noliedz pats galvenais arguments - 1208. gadā fiksētais nelielais attālums no pils līdz Cēsīm (IH, XII: 6), kurš Trikātas gadījumā ir vairāk nekā četrdesmit kilometru. Tas ievērojami pārsniedz hronikā aprakstītā karaspēka maršruta limitu, jo ziṇnesim vēlā rudenī, tumsas laikā bija jāveic ceḷš līdz Cēsīm, kurā vēl kādu laiku tika pulcināts karaspēks. No rīta visi atgriezās atpakal, pilī un tad visu nākamo dienu dzenas pakal igauņiem, bet vakara tumsā uznāca stiprs aukstums un ceḷš sasala. Trikātas virzienā tas summētos līdz pat simt kilometriem, kas vismaz divas reizes pārsniegtu diennaktī fiziski iespējamo jātnieku pārgājiena apjomu. N̦emot vērā Trikātas novietojumu Gaujas kreisā krasta tuvumā, savāds izskatās ziņu trūkums par upes šḳērsošanu sala apstākḷos. Trikātas pilsdrupās izrakumi ir notikuši jau 1889. gadā (Lēviss 1891, 39), un nekas nenorādīja uz koka apbūves pastāvēšanu. Trikātas mūra pils varētu būt celta tikai 15. gadsimtā (Ose, Caune 2004, 511), bet 12.-13. gadsimta koka nocietinājumu atrašanās pašā Strenču meža masīva malā ir nelog̣iska. Jebkurā brīdī kaiminin - igauṇi un krievi - varēja no mežiem pēkšn,i uzbrukt un pili nodedzināt.

Pateicoties F. Baloža centieniem, ir izveidojusies nepamatota pārliecība par Pekas kalna apdzīvotību vismaz no 12. gadsimta. Šeit ir skaidra 
F. Baloža tēva V. Baloža virzošā loma, kurš vēlējās novietot Valmieras tuvumā gandrīz visas nozīmīgākās pilis - Autīni, Beverīnu un Metimni, kā arī paša iztēles uzburto Imeras pili “jaunatklātajā" Cimpēnu kalnā. Pārskatot izrakumu aprakstu (Ballod 1911, 9-14), ir jāpārvērtē kalna senākā slāņa datējums ar 12.-13. gadsimtu. Pilskalna uzbūvē un izrakumu materiālā konstatēta virkne īpatnību, kas neatbilst dzelzs laikmeta nocietinājumiem: 1) plakumam ir regulāra četrstūra forma; 2) plakuma perimetru aptver zems pakavveida valnis trijās apdraudētākajās malās (mūsdienās izzudis); 3) uzeja kalna ziemeḷu pusē ir ierīkota pretēji pilskalnos raksturīgajam principam (t. i., lai vairoga neaizsargātā, labā puse, uzbrūkot būtu pavērsta pret nocietinājumu); 4) sānsienas veido divas paralēlas stāvkoku žoga rindas, kas ierīkotas apmēram piecus metrus no plakuma malas; tām analogi atrodami tikai viduslaiku izrakumu materiālos - Tanīsa kalnā u. c. (Balodis 1928, 22); 5) atrasta guḷūves celtne, kurai apkures pusē bija ḳieǵeḷu mūrējums; 6) atrasti bronzas piekariņi un, iespējams, durvju cilindriskā slēdzene ar cemmi (Ballod 1911, 9), kam paralēles saskatāmas Lucas kalna vācu laika atradumos (Berga 2018, 30). Šāda slēdzene var kalpot par izškirošo norādi, kas l,autu jau pavisam droši apšaubīt senākā slān,a saistību ar dzelzs laikmetu. Atradumi senākajā slānī raksturīgi drīzāk 13.-14. gadsimtam, jo savietojami ar tuvējā Lucas kalna materiālu (Berga 2018, 21). Publikācijā nav attēlots neviens no datēšanai derīgajiem priekšmetiem - nažiem, cirvjiem, pakavsaktām, ķemmēm, vārpstiņām u. c., tāpēc atliek cerēt vienīgi uz orig̣inālu izpēti Maskavā, Valsts vēstures muzejā. Atradumu vidū trūkst militāra rakstura priekšmetu - šḳēpu, bultu un arbaletu uzgalı -, kas apliecinātu pēc hronikas zināmās cīn,as ap Beverīnu. Par skaidru viduslaiku apdzīvotību liecina nocietinājumu uzbūves īpatnības un kopējais atradumu spektrs, līdz ar to F. Baloža apgalvojums par vēlā dzelzs laikmeta slāni šeit nevar tikt zinātniski argumentēts (Balodis 1928, 14).

13. gadsimtā Pekas kalnā vai paša lielceḷa malā, kurš vēl mūsdienās atpazīstams Gaujas kreisā krasta terasē, varēja tikt ierīkota nenocietināta mītne - naktsmītne ordeņa laudīm. Tolaik nepārtraukts meža masīvs no Kauguriem pletās līdz pat Valkai, un tajā ceḷiniekiem bija sagaidāmi dažādi apgrūtinājumi - aukstums ziemā, plēsīgi zvēri, siena trūkums, laupīšanas u. c. Ordeņbrāliem bija vajadzīga arī nocietinātu atbalsta punktu līnija ceḷā no Cēsīm uz Igauniju, un tādi tiek ierīkoti 14. gadsimtā, kuri viens no otra atrodas dienas pārgājiena attālumā - Kauguru Pekas kalnā (vēlāk Valmiera), Burtniekos, Rūjienā (vai Naukšēnos), Karksi Igaunijā. Vēlāk, 14.-15. gadsimtā, kalns pārtapa par nocietinātu ordeņa ārpilsētas muižinuu, kuras atliekas atraka un izpētīja F. Balodis. Ar muižas pastāvēšanas laiku saistāmi raksturīgie atradumi - ḳieǵeḷi, naglas, dakstiņi, keramika, stikli un, galvenais, uz 16. gadsimtu attiecināmie krāsns podiṇi. Iespējams, ka šĩ ir vēl 1601. gadā pieminētās Ūdrenes vakas (Švābe 1933, 546) muižas 
vieta, kurai robežas sakrīt ar vēlākās Kauguru muižas un pagasta aprisēm. No tās uz austrumiem, Miegas upes krastos atrodam Voldenses ciemu (Woldenschen; Švābe 1933, 543). Abu nosaukumu etimologiju varam saistīt ar divām Pekas kalna tuvumā esošajām Gaujas vecupēm. Ja Ūdrene skaidri saistāma ar latviešu ūdrs, otra viegli izskaidrojama ar vācu valodas wald-see (tulkojumā - mežezers).

Valmieras pirmsākumi 13.-14. gadsimtā varēja būt vācu tirgotāju un amatnieku nodibināts atbalsta punkts satiksmei ar Novgorodu, kuru varam piesaistīt Lucas kalna apmetnei (Berga 2018, 21). Taču arheologe Tatjana Berga to raksturo kā vietējo iedzīvotāju - amatnieku un latviešu strādnieku dzives vietu (Berga 2018, 30). Ja Lucas kalns bija tirgotāju apmetne, tad nepilnus desmit kilometrus attālais Pekas kalns uzrāda acīmredzamu saistību ar ordeni. Šāda šķirta apmešanās nav pārsteigums, jo tikai 1330. gadā ordenim izdodas pārvarēt Rīgas pilsētu un sākt kontrolēt Novgorodas tirdzniecību. Jānorāda uz atklājumu, ka 18.-19. gadsimta kartogrāfiskajā materiālā varam atrast Novgorodas senākās tirdzniecības trases pēdas, kas uzrāda ziemas ceḷa trasei sākumu tieši Valmierā. Tā, piemēram, K. Rikera Livonijas guberņas kartē (C. G. Rücker, 1839) vēl ir atpazīstams 12.-15. gadsimta ziemas ceḷš maršrutā Ķeiži-Jērcēni-Ērǵeme. Pie pilsētas Gaujā atradās Kazu krāces, kuras jūras virzienā ir pēdējais vērā ṇemamais šḳērslis, tāpēc uz Rìgu pavasarī varēja nokḷūt arī pa drošu ūdensceḷu.

Mūrmuižas vietā izdodas lokalizēt vēsturē nezināmu 16. gadsimta muižiņu - Volfarti (Wolphart, Wolgarten u. c.), kura kalpoja par ordeņa mestra ārpilsētas rezidenci. Tajā kopš 1540. gada mestrs Hermanis Brigenejs ir apstiprinājis vismaz astoṇus dokumentus (LGU II, 799), bet Livonijas kara priekšvakarā tiek uzsākta tās centra apbūve, no kuras vēl tagad saglabājusies vēsturiskā mūra ēka (Ose, Caune 2004, 341). Par Volfartes un tuvējās Valmieras apkaimes īpašnieku, ordenim sabrūkot, kḷūst Johans Bukhorsts. Viņš ir bagāts un ietekmīgs Livonijas muižnieks (LGU I, 808), dokumentos un hronikās pieminēts vismaz no 1524. gada līdz pat Livonijas kara sākumam. Škiet, ka augstmanis kara laikā iet bojā, un drīz pēc 1560. gada par tā īpašuma pārvaldnieku tiek pieņemts Heinrihs Štādens, gados jauns vācu dēkainis (Dunsdorfs, Spekke 1964, 297). Mūrmuižā saimnieko J. Bukhorsta atraitne, pēc kuras otrajām laulībām no Vācijas ierodas Bukhorsta radinieks un saņem mantojumu. Dokumentos nav konsekvences šì uzvārda rakstībā Buckhorst, Bockhorst, Buckhorsten u. c. (LGU II, 808; Švābe 1933, 542), tāpat arī latviski to varēja izrunāt dažādos variantos, kā Bokarts vai pat Bekerts. Tā kā vietējie iedzīvotāji pilsvietu no seniem laikiem sauca par Bekas vai, visdrīzāk, Beku kalnu (Ballod 1911, 24; Enzeliņš 2019, 292), tad nosaukums Pekas kalns var izrādīties V. Baloža patvalịigi izveidota vietvārda pārskaņa. Šāda forma viņam kalpoja kā būtisks pierādījums Beverīnas novietojumam, jo saskanēja ar hronikā pieminētā pils vecākā vārdu Paike. 
Vairāku Gaujas kreisā krasta vietvārdu - Beku kalns, Bēkurs (divi mājvārdi) un Bēkura tilts - izcelsme jāsaista ar 16.-17. gadsimta Mūrmuižas ìpašniekiem Bukhorstiem.

Tālava pakḷaujas Rīgas bīskapam 1214. gada rudenī (IH, XVIII: 3), tāpēc pirmā Ziemel̦vidzemes (Imera, Tālava, Astigerve u. c.) sadalī̌ana norisinājās laika periodā no 1215. līdz 1216. gadam. Tieši šai laikā tiek nospraustas Rameķa lēņa robežas (terminis Rameke), kuras rakstos piefiksētas daudz vēlāk, tikai 1224. gada Tālavas sadalīšanā (SLVA 79). Būtiska ir Rameķa īpašumu dienvidu puses robeža, kura atdalīja Trikātas novadu no Raunas un Smiltenes. Tā jau ir restaurēta pēc 17. gadsimta pilsnovadu robežām, un Livonijas valstiņu kartē tā iezīmēta kā 16. gadsimta ordeṇa - arhibīskapa robeža (sk. 1., 2. attēlu). Sākotnējā 1214.-1216. gada sadalīšanā Rīgas bīskapa lỉbiešu novadiem tiek pievienots Burtnieku ezera baseins, Imera, Sakala un Rameḳa Gaujas kreisais krasts ar Trikātu. Ordenis dabū Cēsīm un Autīnei piegulošo Tālavas dạ̣u Centrālvidzemes augstienē (Rauna, Dzērbene, Smiltene), kurai Valkas tuvumā bija jāsaiet kopā ar Ugaunijas daḷu. Pirmā Ziemel̦vidzemes sadalīšana labi atspoguḷota Frīdriha Benninghofena pētījumos (Benninghoven 1965, 7. karte; sk. 2. attēlu), kurš par tās norises gaitu norādes ieguvis no 1259. gada priestera Papendorfas Heinriha liecības (Abuls 1924, 45). Hronikā 1216. gada vasarā un rudenī pieminēti tikai pirmie Igaunijas dalīšanas mēǵinājumi (IH, XX: 2; 4), nebilstot ne vārda par Tālavas sadali. Taču Igaunijas dalǐšanu nemaz nebija iespējams uzsākt, netiekot skaidrībā ar tai dienvidos piegulošo latviešu zemju piederību. Apstākḷiem mainoties 1224. gadā, abas daḷas tiek samainītas pretēji, notiek rokāde abpus dabā nospraustajai Rameķa robežai. Beverīnas vārds šai sadalē nekur neparādās, kas liecina par pils atrašanos atstatus no robežām. Savukārt Trikāta 1259. gada liecībā ir pieminēta atseviški, tieši nospraustās robežas tuvumā (Tricatuva; Abuls 1924, 45), un tas vēlreiz izslēdz to no Beverīnas novietojuma saraksta. Hronika 1216. gadā apraksta Beverīnas nodedzināšanu, pēc kuras redzam, ka pils jau ir nonākusi Cēsu ordeņbrāḷu pārzin̄ā (IH, XX: 5). Tā ir būtiska norāde, ka Beverīna 1216.-1224. gada laika posmā ir atradusies zobenbrāḷiem pieškirtajā Tālavas sadaḷā, Vidzemes augstienes ziemeḷu malā. 1224. gadā no Cēsīm uz ziemeḷiem tiek novilkta jauna robeža pa piecām mazām upītēm (Vaidava, Danka, Silupīte, Anuḷa u. c.) līdz Briedei un pa to līdz Burtnieku ezeram. Šeit pieminētais ciems pie Vivas upes (villa apud Viwa; villa Wivan) lokalizējams Cēsu apkārtnē, kur tas varētu būt atradies Tulmenes vakas (Liepas pagasta) teritorijā starp Gauju un Raunas upi. Ordeņa robeža no Burtnieku ezera gāja pa Sedas upi uz augšu un savienojās ar Rameķa robežu Valkas apkārtnē. 1259. gada dokumentā (Abuls 1924, 45) minētais ciems Balaten atradies pie Sedas ietekas ezerā, kur bija vecsaimniecība Baložmuiža, bet ciems Callia identificējams ar vairākām Ķelles mājām Valkas pagastā (igauniski Kelli). Šie trīs ciemi - 
Vivan, Callia un Balaten - izdalīja ordeņa zemju mazapdzīvoto trīsstūri, kuru vēlāk paplašināja uz kaimiņu bīskapijām atṇemto zemju rēḳina, līdz ar ko izveidojās vēstures literatūrā pazīstamais "Gaujas koridors".

Raunas Tanīsa kalnā ir arheolog̣iski pierādīti 12.-13. gadsimta mijas nocietinājumi un apdzīvotība, atklājās fakts, ka šai laikā to mēǵināja nodedzināt, bet daḷa celtṇu palika neskarta un nojaukta tikai pēc ugunsgrēka (Balodis 1928, 33). Arguments, ka Raunas Tanīsa kalnā atradusies Sateklas pils, nebalstās uz uzmanīgu hronikas ziṇu analīzi, jo visas norādes Rusina pili liek meklēt rietumos, starp Siguldu un Cēsīm (Skutāns 2010). Autīne Priekuḷu Sārumkalnā ir acīmredzama, toties Sateklu un Metimni atrast nebūs tik viegli, un šeit nepieciešami jauni arheoloǵiskie izrakumi vismaz trijos pilskalnos. Novietojot Jersikai piederošo Autīnes novadu starp Cēsìm un Raunu - Priekul,os, nav iespējams austrumos no Rauṇa robežupes meklēt arī Sateklu. Tas neatbilst hronikā un dokumentos fiksētajai novadu nonākšanas secībai orden,a varā. Pirmie tiek pievienoti Rusina latvieši, kas, visticamāk, ietilpa līvu novados un pakḷauti ordenim tika jau 1207. gadā (IH, X: 14; XI: 3; XI: 5; XI: 7). Lai arī Autīne atradās tiešā Cēsu tuvumā, Rīgas bīskaps to iegūst pēc Jersikas pakḷaušanas 1209. gadā (IH, XIII: 4; SLVA 38), bet ordenis to main,as ceḷā pārṇem tikai 1213. gadā (IH, XVI: 7; SLVA 56). Tālava ar Beverīnas pili sešus pirmos sadarbības gadus vispār nepieder vāciešiem, ordeṇa pakḷautībā tās trešdaḷa ar Raunas teritoriju nonāk tikai 1214.-1216. gada pirmās sadalīšanas rezultātā. Līdz ar to 1209.-1213. gadā Autīne Vaives krastos kā ķîlis atdalīja ordeni no Raunas novada, un Rūsina novada novietošana šeit nonāk pretrunā ar rakstu dokumentu faktiem. Nekur Vidzemē mēs neatrodam arī vietvārdus, kas būtu cēlušies no vārda sateka, līdz ar ko nenozīmīgā Raunas (arī Raunaisis) un Līčupes sateces vieta augšpus Tanīsa kalna nav nopietni uztverams arguments.

Raunas Tanīsa kalna arheologiskie izrakumi un atsevišksi atradumi pierāda arī viduslaiku perioda, 14.-16. gadsimta intensīvas apdzīvotības pēdas (Balodis 1928, 29-33; Ose, Caune 2004, 377). Populārajā literatūrā sastopamais uzskats par Raunas pils ierīkošanu 1262. gadā izrādās tikai 18. gadsimta hronikas pētnieku patvalīgs pien,ēmums (J. G. Arnts). Dokumentos castro Rownenborgh pirmoreiz pieminēta tikai 1381. gadā (LUB III, 385. sleja), bet apmetne - ville seu palte Rouwnenborch 1471. gadā (LGU I, 428). Viduslaiku apdzīvotība un nocietinājumi konstatēti gan pašā Tanīsa kalnā (Balodis 1928, 29-33; Ose 2004, 380), gan arī pilskalna pakājē - nocietinājumu kontūras - terases un grāvis. Populārajā literatūrā atrodams savāds nostāsts par Raunas pilsētiņas stiepšanos trīs kilometru garumā (Juškevičs 1927, 294), taču tik liela tā nevarēja būt.

Jauns virziens Beverīnas meklējumos ir Baltijas jūras tirdzniecības avotu izpēte, no tiem svarīgākie ir uz 13.-14. gadsimta miju attiecināmie ieraksti Rīgas parādu grāmatā (RS 1872, 1-119). Livonijas pilsētu veido- 


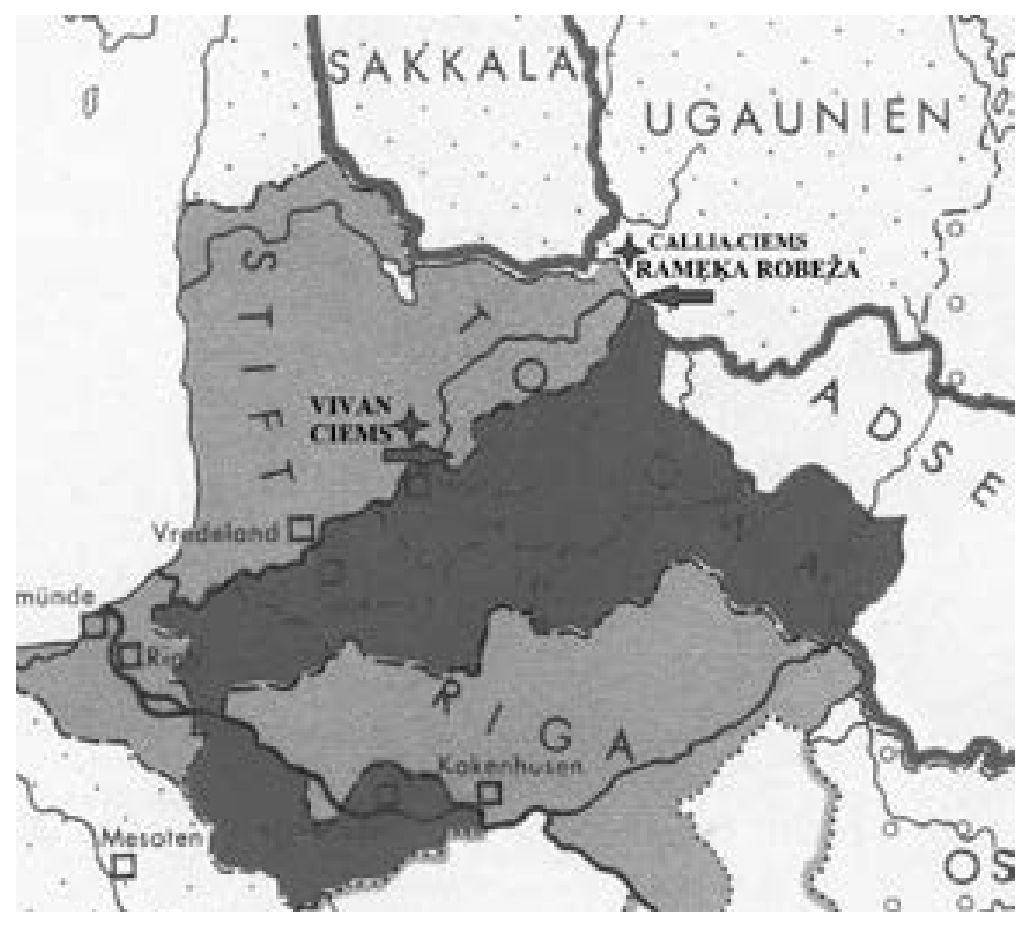

2. attēls. F. Benninghofena sastādītā karte (Benninghoven 1965, 7. karte) par Vidzemes pirmās sadalǐšanas periodu (ap 1216.-1224. gadu). Pelēkā krāsā atzīmēti bīskapa, tumši pelēkā krāsā - ordeṇa īpašumi. Papildināti ar G. Skutāna pieñēmumiem par Rameķa robežas, Vivan un Callia ciemu atrašanās vietām Figure 2. Map compiled by F. Benninghoven (Benninghoven 1965, Map 7) for the period of the first division of Vidzeme (around 1216-1224). The bishop estates are marked in blue, while the order estates - in red. Supplemented with G. Skutāns' inferences about the location of the border of Ramekis, the villages of Vivan and Callia

šanās vēsture ir bijusi aktuāla pētniecības tēma, tāpēc uzmanību piesaista fakts, ka rakstu avotos nav atrodams Raunas pilsapmetnes nosaukums. Gaujas vidustecē tiek pieminētas tādas vietas kā Cēsis, Valmiera, Valka, Straupe un pat Rubene, taču nav ziṇu par Raunu un Trikātu. Parādu grāmatā no Valmieras (de Woldemar) pieminēti sešu personu divdesmit darījumi (RS, 151), bet no Cēsīm (de Wenda) vismaz četrpadsmit personu vairāk nekā četrdesmit ieraksti (RS, 150). Lībekas parādu grāmatā laikā no 1325. gada līdz 1360. gadam uzskaitīti Cēsu pilsētai piederīgu personu četrdesmit darījumu ieraksti un piecdesmit divi galvojumu ieraksti, kamēr Valmiera fiksēta tikai trijos darījumos (Plētiens 2015, 32). Rīgas un Lībekas parādu grāmata norāda uz Cēsu reǵiona vadošo lomu Novgorodas tirdzniecībā 14. gadsimtā. Arī tuvējās Raunas pilsapmetnes tirgotājiem bija jābūt iesaistītiem preču apritē, taču par to ziņas atrast neizdodas. Tāpēc ir 
pamats domāt, ka Raunai tolaik tika izmantots cits nosaukums. Rīgas parādu grāmatā jāpievērš uzmanība piecām personām ar izcelsmes vārdu de Beveren (RS, 124), kuras iesaistītas trīsdesmit astoṇos darijumu ierakstos. Tie ir Dethardus, Andreas, kā arī ar rātskunga titulu apzīmētie Thimmo, brāḷi Iohannes, Heinricus, kuri visi identificējami kā vietējie Livonijas iedzīvotāji. Katrā ierakstā fiksētas arī ar darījumu saistītās personas, starp tiem trīs vidzemnieki - Hermanis un Johans no Valmieras, Lūdolfs no Cēsīm. Taču Vācijas un Livonijas pilsētu (Lībeka, Tallina, Tērbata u. c.) dokumentācijā tirgotāji de Beveren (Bevern, Bevere) tiek pieminēti regulāri - tādi ir raksturīgi visam plašajam lejasvācu dialekta areālam no Holandes līdz Narvai. Vairākumā germāṇu valodu bever nozīmē bebrs, un tas ir bieži sastopams vietvārdos un personvārdos.

Vairākās vietās uz Krievzemes tirdzniecības maršrutiem - Valmierā, Straupē, Raunā un Valkā - pēc 1208.-1224. gada Livonijas izveides parādās nākamo pilsētiņu priekšteces. Tie bija Rīgas tirgotāju veidotie priekšposteñi - atbalsta punkti ceḷā uz Novgorodu un atpakal, sākotnēji nenocietinātas apmetnes. Rauna Livonijas laikmetā kā apdzìvota vieta fiksēta tikai 15. gadsimta beigās, bet tās senākā nosaukuma Beverin nomaiņas iemesls uz Ronneburg ir gaužām vienkāršs. Jāsaprot, ka Rīgas arhibīskapa jaunuzceltajai pilij nosaukums Beverburg ne visai labi piestāvētu. 14. gadsimtā pastāv arī citas bever- tipa vietvārdu un personvārdu saistības ar Raunu, un tādas var vēl atklāties jaunas. Arhibīskapa Fromolda urkundēs Rīgas bīskapijā no 1361. gada septembra līdz 1362. gada jūlijam atzīmēts kāds laicīgās kārtas liecinieks - Teodorihs Beverins (Thidericus Beyeryn; LGU I, 90-92). Šai laikā arhibīskaps dzīvo Vācijā, un kādam vietējam apstākḷu zinātājam bija jādodas pie viņa kā lieciniekam vasaḷu dokumentācijā. Valmiera, Kauguri un Trikāta šai laikā atradās ordeṇa dạ̦ā, bet Rauna pieder Rīgas arhibīskapam. Vēl jāpiemin Bever porten Vecrīgas mūros pie Rīdziñas, mūsdienu Audēju un Kalēju ielas krustojumā (Dambe 1990, 23), kurus 17. gadsimtā nomaina Raunas vārti jau citā vietā, Ģertrūdes un Brīvības ielas krustojumā. Pagaidām Livonijā pieminētās bever- vietas un personas neizdodas nepārprotami saistìt ar Cēsīm vai Raunu, tāpēc nākotnē nepieciešams pētījums par Raunas pilsapmetnes attīstību 13.-15. gadsimta periodā. Ir pamats domāt, ka senākie raunēnieši - pilsētnieki un muižnieki - varētu tikt identificēti arī ar Livonijas dokumentos bieži atrodamajiem personvārdiem Renne, Ronne, Rene u. c. (LGU I, 704; u. c.).

Ieskatoties mūsdienu mežu un purvu masīvu izplatības kartēs, jāsecina, ka teritorija uz ziemeliem no Jumaras un Abula upes 12.-13. gadsimtā bija viens milzīgs mežu un purvu masīvs. To apstiprina arī Igaunijas karagājienu un kauju apraksti hronikā, kur robežu rajonā bieži ir pieminēti meži (IH, XIV: 7; XV: 7). Gaujas vidusteces krastos starp Cēsīm un Valku, kā arī Burtnieka ezera baseinā dzelzs laikmeta pilskalni līdz šim nav konstatēti. 
Ja Kauguros un Trikātā zināmas 12.-13. gadsimta latgaḷu tipa apbedījumu vietas (Beites, Lubu muiža, Kikuts u. c.), Valmieras tuvumā un uz ziemeliem šādu atradumu nav. Lìdz ar to šeit varētu būt pletusies latgaḷu kultūras ziemel̦u perifērija - savdabīgi "mežonīgie ziemel̦i”, kur lauksaimniecībai derīgo zemju apgūšana vēl nemaz nebija sākusies. Gaujas labajā krastā arheologiski nevar fiksēt arī 12.-13. gadsimta nenocietināto apmetnuu pastāvēšanu. Igaunijas karu laikmets 1208.-1224. gadā no šejienes aizbaidīja nomaḷāko viensētu iemītniekus, padarot plašu apvidu uz laiku neapdzīvotu. Lìdz ar to Beverīnas meklējumus varam beigt ar slēdzienu, ka Gaujas krastu mežos senču piḷu pastāvēšanu noraida visvienkāršāko vēsturiskās ǵeogrāfijas un arheologijas datu analīze. Hronika skaidri apraksta pili biezi apdzìvotā zemkopības rajona centrā, kuras iemītnieki kara laikā sapulcējas pilī no tuvējās apkārtnes, šeit pat no viņiem nodevas ievāc Pleskavas krievi.

Beverīnas problēmu radīja pazīstamais skolotājs un novadpētnieks V. Balodis, kurš 19./20. gadsimta mijā popularizēja stāstus par četru senču piḷu atrašanu Valmieras tiešajā tuvumā. Viña dēls F. Balodis to bez ierunām pārñēma un centās pamatot ar arheologijas palīdzību. Viṇa veiktie 1927. gada izrakumi Raunas Tanīsa kalnā izraisīja publisku konfrontāciju ar E. Brastinuu. Tēva un sava prestiža dēl viņš nespēja atteikties no Valmieras hipotēzēm, talkā pieaicināja publicistu J. Juškeviču, kurš izstrādā novadpētnieciska satura rakstu par Raunas vēsturi un novieto šeit Sateklu (Juškevičs 1927, 293). Līdz ar to E. Brastinam zūd iespēja pārliecināt tā laika Latvijas vēsturniekus, bet F. Balodis savu Beverīnu iekḷauj oficiāli akceptētajā Latvijas aizvēstures modelī, kurš līdz šim brīdim nav kritiski pārskatìts. Pēc arheoloǵijas pētījumu ziņām, astoṇās no deviņām būtiskākajām Beverīnas meklējumu vietām neatrodam ne vēlā dzelzs laikmeta nocietinājumus, ne apdzīvotības pēdas, ne arī savrupatradumus. Toties Raunas Tanīsa kalnam atbilst viss hronikā atspoguḷoto pazīmju spektrs, par labu runā arī arheologisko atradumu klāsts. Raunas apvidus vēlā dzelzs laikmetā ir biezi apdzīvots zemkopības rajons (LA, 178), kas atbilst hronikā aprakstītajiem Beverīnas latviešiem un viṇu militārajām aktivitātēm. Pašlaik galvenajam konkurentam - Pekas kalnam - vairāk piestāvētu neliela ordeña koka nocietinājuma loma, bet tā apkārtnes senākie vaku, muižu un ciemu nosaukumi, kā, piemēram, Ūdrene, Volfarte un Voldense, neuzrāda nekādu līdzību ar Beverīnas nosaukumu. Cēsu un Valmieras reǵiona senvietas pēdējos simtpiecdesmit gados ir labi apsekotas, un šeit trūkst ziņu par kādu vēsturei zudušu, nopostītu pilsvietu. Pēc aerolāzera skenēšanas tehnoloǵiju parādīšanās (LIDAR) jaunu pilskalnu atklāšanas iespējamība šajā apvidū vērtējama kā nereāla. Iespējams, ka Beverīnas meklējumus neatgriezeniski varēs beigt tikai jauni izrakumi Pekas kalnā un Trikātas pilsdrupās. Beverīnas problēmu būtu laiks atstāt pagātnei, jo ir vēl daudz aktuālākas tēmas pagātnes mantojuma apzināšanā. 
Šĩs publikācijas saturs nonāk pretrunā ar Beverīnas novada vietējo novadpētnieku un vēstures interesentu gadu desmitos veidotajiem uzskatiem, bet tēze par senču piḷu neesamību šai apvidū liksies pavisam nepievilcīga. Vinuus vajadzētu uzslavēt par centieniem kopt un popularizēt dzimtās puses pagātnes mantojumu un atgādināt, ka no jauna atklātā Valmieras, Mūrmuižas un Trikātas vēsture var izrādīties ne mazāk interesanta un ar savu patiesumu daudzreiz vērtīgāka. Esmu pārliecināts, ka tuvākajā nākotnē iesaistīties pētnieki un entuziasti spēs vēlreiz sanākt kopā uz meklējumus noslēdzošu, labdabīgu domu apmaiņu.

\section{SAĪSINĀJUMI}

IH - Indriķa hronika

EE - Eesti easiajalugu (Igaunijas arheologija)

LA - Latvijas arheologija

LGU - Livländische Güterurkunden, Band I, II

LUB III - Liv-, Est- und Kurländisches Urkundenbuch, Band III

RS - Das Rigische Schuldbuch (Rīgas parādu grāmata)

SLVA - Senās Latvijas vēstures avoti, 1.-2. burtnīca

\section{IZMANTOTIE AVOTI UN LITERATŪRA}

Abuls, P., 1924. Kur atradās Beverīna? Vēsturisks apcerējums. Rīga, 75. Pieejams: https:// dom.lndb.lv [Skatīts 1.05.2021.]

Apals, J., Apala, Z., 1988. Izrakumi Vaidavas pilskalnā un Raunas pilsdrupās. Zinātniskās atskaites sesijas materiāli par arheologiijas un etnogräfijas 1986. un 1987. gada pētijumu rezultātiem: arheologija. Rīga, 16-19.

Auns, M., 1996. Jauna versija par Beverīnu. Latvijas Vēstures Institūta Žurnāls, 3 (20), 109-123.

Ballod, F., 1910. Nekotorye materialy po istorii latyshskogo plemeni s IX po XIII stoletie. Zapiski Moskovskogo Arheologicheskogo instituta. Tom 9. Moskva, 125.

Ballod, F., 1911. Otchet o komandirovke v Pribaltijskij krai letom 1909 goda (Beverinskii raskopki). Trudi Moskovskogo predvaritelnovo komiteta po ustroistvu XV Arheologicheskogo sjezda. Moskva, 26.

Balodis, F., 1928. Tanīsa kalnā izdarītie izrakumi un konstatēto mītnes slāņa kārtu datējums. Archailogiijas raksti, 4. sējums, 1. daḷa. Rīga: Pieminekḷu valde, 19-39.

Benninghoven, F., 1965. Der Orden der Schwertbrüder: fratres milicie Christi de Livonia. Köln: Böhlau Verlag, 525, 16 Karten.

Berga, T., 2018. Valmieras vecpilsētas arheologiija. Rīga: Zinātne, 208.

Brastiņš, E., 1930. Latvijas pilskalni: Vidzeme. 4. daḷa. Rīga, 210.

Brūzis, R., Berga, T., 2020. Arheologiskie pētījumi Valmieras pilsdrupās 2018. gadā. Arheologu pētijumi Latvijā 2018.-2019. gadā. Rīga: NT Klasika, 69-73.

Dambe, V., 1990. Rīgas ielu nosaukumi. Onomastica Lettica. Rīga: Zinātne, 21-32.

Dunsdorfs, E., Spekke, A., 1964. Latvijas vēsture: 1500-1600. Stokholma: Daugava, 797. 
Eesti esiajalugu. 1981. Tallin, 464.

Enzeliņš, H., 1935. Beverīna - Valmierā. Valmierietis, 31. oktobris, 8., 22., 29. novembris.

Enzeliņš, H., 2019. Skati Valmieras pilsētas, draudzes un novada pagātnē. Valmiera: Apvārsnis.

Indrik,a hronika. Ē. Mugurēviča komentāri. Rīga: Zinātne, 1993, 453.

Jemeljanovs, E., 2010. Izrakumi Siguldas Krusta kalnā. Arheologu pētijumi Latvijā 2008.2009. gadā. Rīga, 125-127.

Juškevičs, J., 1927. Rauna. Izglïtibas Ministrijas Mēnešraksts. 10 (94), 285-295.

Kraukle, R., 2016. Arheoloğiskie izrakumi Liepupes pilskalnā 2015. gadā. Arheologu pētijumi Latvijā 2014.-2015. gadā. Rīga: Nordik, 186-188.

Latvijas arheoloǵija. 1974. Rīga, 374.

Lauris, E., 2019. Kur atradās Beverīnas koka pils? Valmierā vai tomēr zem Trikātas mūra pilsdrupām? Beverinas Vēstis. 11 (88), 6. Pieejams: www.beverinasnovads.lv [Skatits 01.05.2021.]

Löwis of Menar, K. v., 1891. Die Deutsch Ordensburg Trikaten in Livland. Sitzungsberichte der Gesellschaft für Geschichte und Altertumskunde zu Riga aus den Jahren 1873-1934. Riga, 37-50.

Livländische Güterurkunden (aus den Jahren 1207 bis 1500), Band 1. Bruiningk, H., Busch, N. (Hrsg.). Riga: H. W. Häcker, 1908, 788.

Livländische Güterurkunden (aus den Jahren 1501 bis 1545), Band 2. Bruiningk, H., Busch, N. (Hrsg.). Riga: H. W. Häcker, 1923, 923.

Liv-, Est- und Kurländisches Urkundenbuch, Band 3. Bunge, F. G. (red.). Reval, 1857, 800.

Lucāns, A., 1996. Diletants meklē Beverīnu. Liesma, 22, 4.

Ose, I., Caune, A., 2004. Latvijas viduslaiku pilis: Latvijas 12. gadsimta beigu - 17. gadsimta vācu piḷu leksikons. 4 sēj. Rīga, 591.

Plētiens, E., 2015. Livonijas mazpilsētas: kas tās bija, un kāda bija to ietekme? Latvijas Vēstures Institūta Žurnāls, 3 (96), 5-44.

Das Rigische Schuldbuch (1286-1352). S.-Petersburg, 1872, 232.

Skutāns, G., 1992. Ceḷ̌š uz Beverīnu? Latvijas Vēsture, 4 (7), 61-67. Pieejams: www. historia.lv [Skatīts 11.02.2021.]

Skutāns, G., 2010. Satekla Ligatnes pilskalnā. Pieejams: www.ligatne.lv [Skatīts 11.02.2021.]

Spekke, A., 1995. Latvieši un Livonija 16. gadsimtā. Rīga: Zinātne, 267. Fragments pieejams: $w w w$.historia.lv [Skatits 01.05.2021.]

Švābe, A., 1933. Die älteste schwedische Landrevision Livlands (1601). Latvijas Universitātes raksti. Tautsaimniecỉbas un tiesỉbu zinātnnu fakultātes sērija. 2. sējums, 3. burtnīca. Rīga, 337-596. Pieejams: https://dom.lndb.lv [Skatīts 01.05.2021.]

Senās Latvijas vēstures avoti. Latvijas vēstures avoti. A. Švābe (red)., 1937. 2. sējums, 1. burtnīca. Rīga: LVI.

Urtāns, J., 1991. Ziemel̦idzemes pilskalni. Rīga, 70.

Urtāns, J., 1995. Latvijas austrumu daḷas jaunatklātie pilskalni. Rīga, 128.

Vasiḷausks, E., 2014. Žagares II (Žvelgaiču) pilskalns 13.-17. gs.: no koka pils līdz koka muižai. Arheoloğija un etnogrāfija, 28. laidiens. Rīga, 97-108.

Žīgurs, E., 2003. Beverīnas pilsvietas lokalizācijas problemātika. Pieejams: www.historia.lv [Skatīts 11.02.2021.] 


\title{
SOLUTION TO THE PROBLEM OF SEARCH FOR BEVERINNA CASTLE
}

\author{
GINTS SKUTĀNS \\ Mg. hist. \\ E-mail: skutans@inbox.Iv
}

\begin{abstract}
The search for Beverinna Castle, which is referred to in The Livonian Chronicle of Henry (Latin: Heinrici Cronicon Lyvoniae), has spanned over one hundred and fifty years, nevertheless, to date it has not been possible to reach a unified conclusion as to its location. Currently, the research of archaeological excavations and written sources has enabled elimination of the majority of the castle sites in the vicinity of Valmiera, since this locality is entirely devoid of any finds attesting to its population during the $11^{\text {th }}-13^{\text {th }}$ century.

The analysis of the structure of Kauguri Pekas hill and the excavation material, the existence of the fortification can be attributed only to the $14^{\text {th }}-16^{\text {th }}$ century. Thus, the localization of Beverīna can be performed only on the remaining Rauna Tanisa hill, which meets all the criteria recorded in the chronicle. Archaeological studies of the hillfort yield a significant late Iron Age fortification, but the population of the adjacent region is characterized by a dense concentration of archaeological monuments. As no forthcoming publications of historians are expected to continue the search for Beverīna, we can consider this mystery of the past solved.
\end{abstract}

Keywords: Beverīna, hillfort, castle, historical geography, Livonia, Chronicle of Henry, Middle Ages.

\section{SUMMARY}

In Chronicle of Livonia, place name "Beverīna" is mentioned with regard to Talava county fortress (1208-1216) and as the starting point for the campaigns to Estonia. Despite 150 years of searching, historians have not been able to agree on Beverinna's whereabouts. The search encompassed several hillforts and stone masonry castle sites along the River Gauja in the middle of the basin, around the regions of Valmiera and Cēsis. At present, the details of the chronicles and the evidence of archaeological excavations allows to exclude the locations from the list of options one by one. Consequently, problems in search for correct localization were linked to the incompetence and biased approach of the first researchers, as they looked 
for a castle closer to their native land. The documents of $13^{\text {th }}-14^{\text {th }}$ centuries were scarcely used for the record of the research. These documents allow to understand the development and geography of trade in this period. The place mentioned in these sources as Beverina was found to be connected to Rauna and thus could end three centuries of uncertainty. 